\title{
Is there a crisis of European democracy? The political condition of our time
}

\author{
Peter Wagner
}

\begin{abstract}
Linking historical comparison to conceptual reflection, this article critically discusses the widespread thesis that we are experiencing a profound crisis of European democracy today. One certainly observes rising illiberalism, authoritarianism and what is called populism in Europe and elsewhere. But looking only half a century backwards, there were dictatorships in the South of Europe, there was widespread elite understanding for the coup d'état in Chile, and the commitment to democracy as the only legitimate form of government was much less diffused than today. Having placed current democracy in context, it becomes clear that the current diagnosis of crisis is unclear about its focus. Democracy could be in crisis because there is no space for the will of the people to be expressed, because the will of the people is not translated into government policies, or because the communication between citizens is inadequate for will formation. Without clarifying in which of these senses current democracy is deficient, it will not be possible to arrive at a fruitful understanding of the state of current democracy.
\end{abstract}

Keywords: Authoritarianism, citizen disaffection, civic activism, democratisation, political communication.

Author: Peter Wagner is Research Professor of Social Sciences at the Catalan Institute for Research and Advanced Studies and at the University of Barcelona. Currently he is also Project Director at the Ural Federal University in Ekaterinburg. His recent publications include Collective Action and Political Transformations: The Entangled Experiences of Brazil, South Africa and Europe (with Aurea Mota, 2019, Edinburgh University Press); European Modernity: A Global Approach (with Bo Stråth, 2017, Bloomsbury); and Progress: A Reconstruction (2016, Polity Press).

peter.wagner@ub.edu

(C) The author(s) 2020. This is an open access article licensed under a

Creative Commons Attribution-NonCommercial-NoDerivs 4.0 Unported License 
Do we live today in a particularly difficult or turbulent political period? This question is more and more often raised in both scholarly and public debates, and the starting assumption is that it will be answered affirmatively. More specifically, it is assumed that we are experiencing a crisis of European democracy, or even a decline of democracy globally. The term 'post-democracy'-like its predecessors, 'post-industrial society' during the 1960s and 'post-modernity' during the 1980s - has spread very quickly and widely after it was coined at the very beginning of this century. Colin Crouch has proposed that the decline of those social classes which had made possible an active and critical mass politics has combined with the rise of global capitalism to produce a self-referential political class more concerned with forging links with wealthy business interests than with pursuing political programmes which meet the concerns of ordinary people. ${ }^{1}$ Often regardless of - and in some cases presumably in ignorance of - this analysis, it has seemed easy to accept that the core democratic self-understanding of many societies has been profoundly undermined in actual political practices. The rapid rise of authoritarian political projects in recent years feeds into such a perception.

At a closer look, however, it is not easy to discern what precisely is meant by the diagnosis of a crisis of democracy. Rather, one can identify two quite different meanings of the term. From the 1990s onwards, the key problem was called 'citizen disaffection'. Given that changes in government did not result in any substantive policy changes, voter participation in elections dropped and citizens turned away from politics. The former UK Prime Minister Margaret Thatcher's phrase 'there is no alternative' hung like a shadow over this period. This changed early in the century, in particular after the financial crisis of 2008 and its follow-up in terms of austerity politics and rising social inequality. 'There has to be an alternative' was what citizens seemed to be increasingly thinking, not least in the southern European countries particularly affected by the policy fallout of the financial crisis. The emergence of the indignados movement in Spain and somewhat later the new political party Podemos, and in Greece the rise of the small leftist alliance Syriza to become a government party, were the most widely discussed examples of a new civic activism. In similar ways, but with different ends, the campaigns for the UK to leave the European Union and for Catalonia to secede from Spain showed new forms of citizen engagement, in these cases in highly polarising form. This new activism was often labelled populism, mostly to suggest that such political participation was undermining the existing democratic institutions. Over a short span of time, paradoxically, it was possible to suggest that both civic disaffection and civic engagement could be a sign of a crisis of democracy. The following reflections are meant to elucidate this paradox further and provide some wider perspective on the political condition of our time.

${ }^{1}$ Crouch (2004). 


\section{RECEDING TIDES?}

To start, one needs to widen the historical horizon. The Spanish novelist and essayist Javier Marías recently reflected in his regular column in the periodical El País Semanal about the ways in which the world has been transformed since the beginning of this century. ${ }^{2} \mathrm{He}$ agreed with the widespread opinion that these transformations were highly worrying, but then took a step back. If we move from observations about the recent past to the beginnings of the 19th and 20th centuries, then our current experience pales in comparison. Between 1800 and 1818, the world had gone from revolution to reaction, passing through major warfare. Between 1900 and 1918, the proud march of industrial progress, celebrated in World Fairs, had led to the mass slaughter of the First World War. While Marías ominously concluded by hoping that the years 20392045 will not resemble the related period of the preceding century, his reflections overall require us to look carefully at longer term historical developments before rushing to firm conclusions about the present.

The aftermath of the First World War witnessed the apparent breakthrough of modern democracy, at least in formal terms. While democracy had been on the agenda in the revolutionary events of the late 18th century, the 19th century rather saw the 'persistence of the Old Regime', as historian Arno Mayer put it. ${ }^{3}$ The year 1919, though, marked the introduction of free and equal universal suffrage in many countries (even though restricted to male citizens in quite a number of them-an important qualification). Political scientists would later speak of a first 'wave of democratisation'. This metaphor seems to suggest that the waters will also eventually recede, but the force of the tides cannot be stopped. Drawing on natural occurrences, the metaphor removes democracy from human agency and imagination. Thus, it is unfortunate in many respects. Rather than bringing us insights about democracy, its use says something about how political analysts see this peculiar political phenomenon. Tellingly, the metaphor manages to insinuate both a law-like nature of democratisation and a high degree of unpredictability. It seems to suggest, ironically, that human action can do a little to mitigate the forces of democracy, but nothing to promote them-in contrast to recent rhetoric about 'promoting democracy', which interestingly is always meant to be pursued abroad and never at home. The metaphor also connects processes of very different kinds, namely a recurrent one, 'waves', and one that is mostly considered as linear, 'democratisation', one of the many supposed trends of modernisation. In other words, the image seems to suggest that every further wave will advance beyond the point where the preceding one has stopped.

${ }^{2}$ Marías (2018).

${ }^{3}$ Mayer (1981). 
If we briefly look at the supposed 'receding wave' of the period between the two world wars of the 20th century, it is easy to recognise that the destruction of democratic institutions in many countries was far from predetermined, but something consciously brought about in the interaction between existing elites and new political actors. No wave was receding; if there was one, it was brought to a halt and the waters pushed back. Furthermore, these interactions took place relatively shortly after democratic rules had been introduced, often half-heartedly, more because of the absence of alternatives than out of conviction in their normative superiority or functional viability. And we should also note that democratic institutions were undergoing rather similar challenges in many countries, but they collapsed only in some. Where they collapsed, they were often recreated only after the military defeat of democracy's opponents or after a profound crisis of the non-democratic alternatives.

Thus, those events lend themselves to some general insights that are not widely shared by current political observers. Firstly, democracy is misunderstood as a political phenomenon that tends naturally towards extension over time, not even in 'cyclical' form. Secondly, democracy's fragility largely comes from within; there is a permanent risk of self-cancellation. ${ }^{4}$ Thirdly, there are no conditions under which democratic institutions necessarily break down; their implosion can be resisted. Fourthly, the capacity for avoiding self-cancellation resides less in institutional design than in a commitment to democratic processes, in a democratic societal self-understanding.

It should be added here that there are also specific features of the interwar constellation that need consideration. These features figure strongly when parallels between the current political situation and that of the interwar period are drawn, and they are striking indeed: the Great Depression is compared with the financial crisis triggered in 2008 and its impact on the socio-economic situation of many citizens; one observes an apparent repetition of the rapid rise of exclusionary and xenophobic nationalism as well as a quickly decreasing support for the supposedly established democratic political forces. Furthermore, the assault on democratic institutions now uses new means of political communication. What were then the early 'mass' media are now the 'social' media. In either case, the media lend themselves to encouraging as much as weakening democracy, but their potential was and is put to effective use by those with an interest in weakening democracy by apparently democratic means. These are without doubt significant parallels, but they are often too easily and too quickly drawn, tending to dramatise current events and even implying some degree of inevitability.

${ }^{4}$ Karagiannis (2016). 


\section{THE LAST HALF CENTURY: DEMOCRACY AFTER 'DEMOCRATISATION'}

Reflection on the interwar crisis of democracy is useful, but it has its limits. To avoid premature conclusions from this specific historical comparison, it is helpful to place the current challenges to democracy in their own context, which is that of the past half century, and to bear in mind the general insights mentioned above, which help to avoid succumbing to socio-economic and historical determinism. Thus, the guiding question would be: What informs the perception that we experience a crisis of democracy that puts at risk the supposed achievements of our 'consolidated democracies'? Has the democratic quality of our institutions and commitments significantly declined over the past half century?

Let us consider some of the societies that are often mentioned today as examples of the retreat of democracy, such as the United States of Donald Trump, the Hungary of Viktor Orbán, the Brazil of Jair Bolsonaro, 'state capture' in South Africa, so-called populist movements coming to power in southern Europe, and then let us compare the present with the situation a half century ago. In the US, civil rights activist Martin Luther King and presidential candidate Robert F. Kennedy were assassinated in 1968. In Central Europe, the so-called Prague Spring was suppressed by the military intervention of the Warsaw Pact forces led by the Soviet Union. In Brazil, a military dictatorship was installed in 1964. In South Africa, the apartheid government increased its oppression of the majority of the population. In southern Europe, Spain and Portugal's authoritarian regimes had persisted since the 1930s, and Greece witnessed a coup d'état that brought a military junta to power in 1967. In direct comparison with the year 1968, the year 2018 does not appear to provide a particularly bleak image of democracy.

But to get closer to an answer to our questions above, we need to introduce temporality into this static comparison of two moments in time. Three aspects are important. First, while 1968 was a year in which authoritarianism was a dominant approach to government in many parts of the world, the year also saw an intensification of political contestation, much of which was aiming at strengthening democracy. The Prague Spring was paralleled in Western Europe by the students' and workers' protests that came to be known as 'the two red years' or, more briefly and lastingly, '1968'. Similar campaigns occurred in Latin America, leading in Chile to the formation of a government aiming for radical social transformation.

The potential significance of these movements was noted with concern by the elites. Those who invoke a 'crisis of democracy' today should be aware of the fact that this was exactly the main title of a report by the Trilateral Commission issued in 1975, which emphasised 'governability' problems in Western democracies. ${ }^{5}$ The report

${ }^{5}$ Crozier et al. (1975). 
shows, indirectly, that the doubts among the elites about the viability of democracy had never entirely disappeared. They were clearly not as pronounced as in the early 19 th or in the early 20th century, and complete rejection of democracy was no longer an option. But one also has to note that the rather lukewarm elite commitment to democratic institutions was limited to the so-called advanced democracies. The authoritarian governments in southern Europe all ended in 1974/5, but the military coup in Chile in 1973 had Western understanding and support. And Javier Cercas's masterful reconstruction of the attempted coup d'état in Spain in 1981 shows how fragile and conditional the elite commitment to democracy was at that moment. ${ }^{6}$ The elites' concern, namely, was above all the smooth and proper functioning of social institutions, not least economic institutions. The question whether this functioning could be secured by democratic means was a secondary concern - and has largely remained so from this angle. What was seen as excesses of democracy from the late 1960s onwards was interpreted as a clear sign of 'crisis' of democracy only because 'governability' seemed no longer guaranteed. When surveys today report about a decline in the citizenry's previously very high commitment to democracy, as they do for some countries, then this should be seen in the context of prior elite disaffection and the public expression of this disaffection.

What we see today as a profound crisis of democracy, is better understood as a consequence of, and reaction to, actual 'democratisation' that happened on an almost global scale during the closing decades of the 20th century. Political scientists describe the recent end of restrictive regimes of various kinds as a 'third wave of democratisation', supported by figures on the number of countries that have formally democratic regimes. On those counts, they can even identify elements of a recently receding tide, with the recent rise of authoritarian-minded political movements. But these observations should hardly amount to announcing a crisis of democracy, and this is for two very different reasons. On the one hand, one should note that-until now-formal democratic institutions have not been abolished in any of the countries in which rising populism and authoritarianism are observed. On the other hand, observations on the very recent trends should be set in the context of the political experience of an intensification of democracy of an unprecedented kind during the past half century.

${ }^{6}$ Cercas (2012 [2009]). 


\section{THE PARADOX OF DEMOCRACY}

Karl Mannheim coined the term 'fundamental democratisation' for the political changes after the First World War, and he had mainly the rapid and full granting of universal suffrage in mind, in particular for the case of Weimar Germany. ${ }^{7}$ His term gained its full meaning at the end of the 20th century. In many - not all — cases of democratisation then, the suffrage was not 'granted' but claimed and seized by an often highly politically active population, with intense participatory processes going on at least temporarily. Key examples are '1968' and its aftermath in Europe, or post-apartheid South Africa and post-dictatorship Brazil in the Global South. ${ }^{8}$ Thus, democratisation became truly 'fundamental' because it started to include the majority of the population in a direct way.

However, this increase in political participation coincided - and not 'coincidentally' - with a decreasing capacity of governments to shape society, given the higher degree of global connectedness, in particular through extended chains of economic production and exchange, but also in cultural terms. Much public and scholarly debate attributes this decline in political capacity to 'globalisation', as if there were a process external to socio-political life and driven by its own logics. But on looking closer, it can be seen that the extension of economic relations across state boundaries was a political project that emerged in the 1960s and 1970s in response to higher levels of contestation which could no longer be contained by abolishing democratic forms. Thus, a core feature of the political condition of our time is the coexistence of a vibrant civil society and citizenry, capable of making legitimate claims, or at least understandable ones, with democratic political institutions that have become unable to address these claims in any satisfactory way. It seems inappropriate to call this constellation a crisis of democracy: political participation is high and democratic institutions persist. The problem is rather the mismatch between the two components of the constellation, which may be higher than at any moment in the history of modern democracy.

This is indeed the key to understanding the current paradox of democracy. On the one hand, we witness high levels of political participation, both 'conventional' in elections and referenda and 'unconventional' through protest actions. On the other hand, citizens often have the impression that their opinions do not count and that their interests are not followed. This has led to disaffection in a first stage and to new forms of engagement in a second. This discrepancy shows that democratic politics needs to rest on at least two pillars - or indeed on three, as we will see in a moment:

\footnotetext{
${ }^{7}$ Mannheim (1940 [1935]).

${ }^{8}$ Mota \& Wagner (2019).
} 
the expression of a popular will and the transformation of this will into effective substantive policies. Observing this discrepancy, parts of the political class have started to mobilise the citizenry for political projects that cannot reasonably be realised, by which we mean that they cannot be realised in such a way that the expectations which have been aroused can be met. This mobilisation is what is often called 'populism', misnaming something that is mainly action by elites and not by the people.

That this discrepancy arises is a permanent possibility under democratic conditions. Its forceful emergence today shows what is weak or missing between the aforementioned two elements: the third pillar of democratic politics, namely political communication of a quality that would enable citizens to identify both the effective limits to government action under current conditions of global interconnectedness and the need for strengthening government capacity to deal with the urgent problems of our time. Governments and political parties spend an enormous amount of time, energy and resources on political communication. They sense that citizens easily escape from their grip and remain unconvinced of their actions. But most of this communication is only instrumental and strategic. It is nothing more than a tool in party competition, aiming at aggregating the preferences of millions of individual voters in selected strategic moments, rather than communicating with interacting citizens with a view to identifying workable solutions.

\section{REFERENCES}

Cercas, J. (2012 [2009]), The Anatomy of a Moment, translated by Anne McLean (London, Bloomsbury Publishing).

Crouch, C. (2004), Post-democracy (Cambridge, Polity Press).

Crozier, M. Huntington, Samuel P. \& Watanuki, Joji (1975), The Crisis of Democracy: On the Governability of Democracies (New York, New York University Press).

Karagiannis, N. (2016), 'Democratic Surplus and Democracy-in-failing: On Ancient and Modern Self-cancellation of Democracy', in Gerard Rosich \& Peter Wagner (eds) The Trouble with Democracy: Political Modernity in the 21st Century (Edinburgh, Edinburgh University Press), 90-109.

Mannheim, K. (1940 [1935]), Man and Society in an Age of Reconstruction (London, Routledge).

Marías, J. (2018), 'Siglo medievalizante', El País Semanal. https://elpais.com/autor/javier_marias/a Mayer, A. (1981), The Persistence of the Old Regime: Europe to the Great War (London, Verso Books).

Mota, A. \& Wagner, P. (2019), Collective Action and Political Transformations (Edinburgh, Edinburgh University Press). 
To cite the article: Peter Wagner (2020), 'Is there a crisis of European democracy? The political condition of our time', Journal of the British Academy, 8(s1): 53-61.

DOI https://doi.org/10.5871/jba/008s1.053

Journal of the British Academy (ISSN 2052-7217) is published by

The British Academy, 10-11 Carlton House Terrace, London, SW1Y 5AH

www.thebritishacademy.ac.uk 
